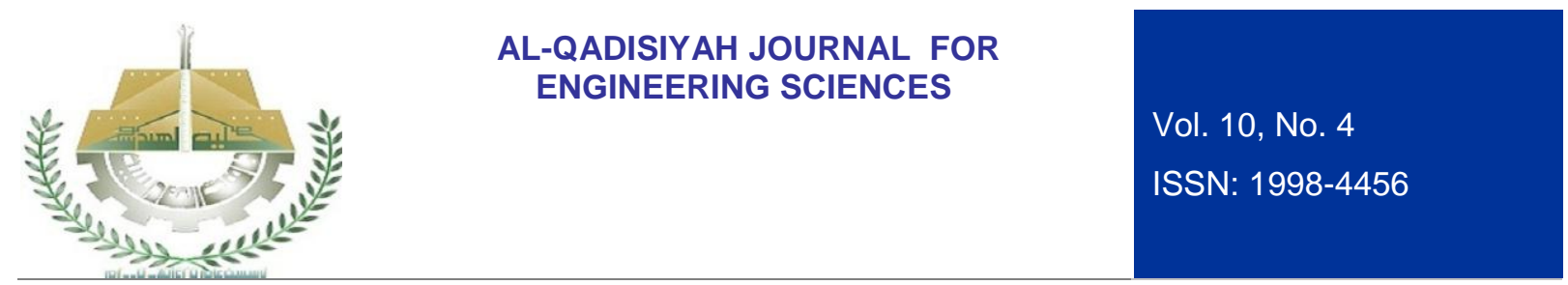

\title{
EFFECT OF DATES NUCLEUS POWDER ON SOME ENGINERRING PROPERTIES OF CLAYEY SOIL IN COMPARISON TO LIME
}

\author{
Yahya K. Atemimi, \\ University of Babylon, Civil engineering department, Iraq-Hilla. \\ E-mail: Eng.yahya.kadum@uobabylon.edu.iq ,yehyeaaltemimi@yahoo.com
}

\begin{abstract}
Abdulla T. Fahad,
Higher Education Candidate - University of Babylon, Civil engineering department, Iraq-Hilla. E-mail: Abdullahtalip9447@gmial.com
\end{abstract}

Received on 10 October 2017 Accepted on 31 October 2017 Published on 15 February 2018 DOI: $10.30772 / q j e s . v 10 i 4.501$

\begin{abstract}
Clayey soils are widely spread over the world. The clay soils are used and need to improve it's engineering properties. Therefore, the treatment is considered one of the available solution for this purpose. Due to the nature of clay particles a trice plasticity, highly in surface area and the ion exchangaple ...etc. these properties encourage the idea of using pozzolanic materials, particularly the lime as pozzolana source.The alternative source of pozzolan is a metakaolin materials generated from burning the organic materials which are widely available in Iraq (i.e. Dates nucleus). The Dates nuclei is a waste material, so these additives can help in reducing the contamination and improving the environment. In this study, dates nuclei powder (DNP) was used after burning it at $900^{\circ} \mathrm{C}$ for one hour and then mixed it with clayey soil in different by weight percentages. Hence, four percentages are selected (5\%, 7.5\%, 10\%, and 15\%) to study the effect of each addition on the shear strength of the clayey soil and the results are compared with the same soil that treated with lime. Many tests were conducted on (the natural clay, clay-DNP and clay-lime) to evaluate the engineering characteristics and to explore best percentages that can used. Curing time (0, 7, 14, 28,90 and 180 days) was used to evaluate the effectiveness of pozzolanic reaction (emerges from DNP-soil mixture) with time. Interested results are found, the shear strength was increased to about six folds for $10 \%$-DNP-soil at 180 days of curing. The liquid limit, plasticity index and the maximum dry density decreased in all percentages of DNP-Clay mixtures. On the other hand, the shear strength increment for DNP-Clay mixture after 180 days of curing is higher than that of Lime-Clay mixture for same period of curing. Forthermore, CBR results increased by six times for $10 \%$ DNP-Clay mixture for un-soaking conditions, while at soaking conditions, the increase was more than eleven times. The lime addition increase the CBR-value about three and eight times for unsoaking and soaking conditions, respectively.
\end{abstract}

Keywords: Clay-Lime, Soil improvement, Pozzolana, Dates Nuclei, CBR. 


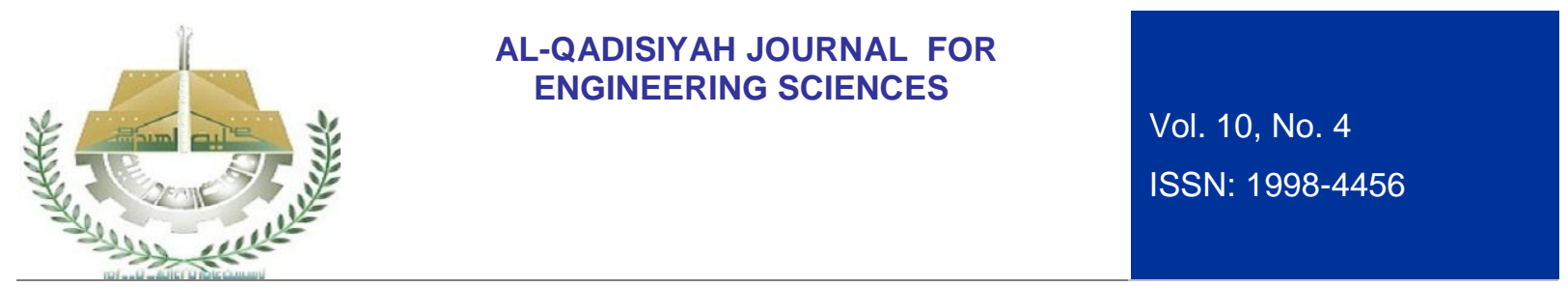

\section{INTRODUCTION}

The speedy growing in population forced some clients to use bad soils quality in different construction projects due to the scarcity of soil in the urban areas. However, the engineers cannot use this type of soil without treatment before use. Therefore, different methods of soil treatment are used and the researchers trying to find the most cheaply and easy methods. The cement and the lime are oldest additive materials that used in soil improvement to increase the soil strength and decrease the compressibility by cementing agents (1). Chemical additives have been used in a wide range (i.e. SBR, Asphalt ...etc) (2). Many researchers (i.e. 3 , 4) studied soil treatment using lime mixed with another additives to improve the workability and reduce the total cost. Pozzolanic reaction in clayey soil is activated due to the chemical behavior between clay particles and the alumina $\mathrm{Al}_{2} \mathrm{O}_{3} \cdot 2 \mathrm{SiO}_{2}$ leads to produce calcination effect on the soil system and this is the main effect of improvement (5). On the other hand, the physical soil properties (i.e. the plasticity) are strongly influenced by the pozzolanic reaction due to the agglomeration and flocculation effect on the fine soil particles and decrease the surface area (6). Many researchers are used several materials (like fibers, bottom ash, rice husk ash ...etc) to improve engineering properties of soil, $(7,8,1)$. The waste materials need tens of millions dollars annually to dispose off. Therefore, using the waste materials in soil improvement can produce two advantages: first, cleaning the environment with low cost and second is to develop new materials that improve soil properties. Today the recycle offal is a new science approach which named green technology. In this study, the date's nuclei powder was used as an additive to improve the shear strength of clayey soil. Increasing soil toughness by adding DNP are promising to use it for different layers if used, for example, in a road construction projects. On the other hand, the material used in this study is of no bad health effect on human or animals.

\section{MATERIALS}

\subsection{THE SOIL USED}

The soil used in this study is clayey soil and was brought from Al-Hilla city around University of Babylon, the location coordinate is E442509.8, N322819.0 at $2.0 \mathrm{~m}$ below ground surface. The soil was then grinded to obtain homogenous soil mass. The soil was classified according to the Unified Soil Classification System ASTM D2487 (9) and found to be of fat clay with high plasticity (CH). Some soil properties are presented in Table 1,Figure 1 also shows grain size distribution curve.

Table 1: basic geotechnical

properties of soil used.

\begin{tabular}{|c|c|}
\hline Properties & Soil \\
\hline$G_{s}$ & 2.71 \\
\hline Color & Brown \\
\hline LL, $\%$ & 65 \\
\hline$P L, \%$ & 30 \\
\hline$P I, \%$ & 35 \\
\hline $\begin{array}{c}\text { \% finer }<0.002 \\
\mathrm{~mm}\end{array}$ & $58($ check $\mathrm{it})$ \\
\hline$M D D, \mathrm{~g} / \mathrm{cm}^{3}$ & 1.56 \\
\hline OMC, $\%$ & 24 \\
\hline
\end{tabular}



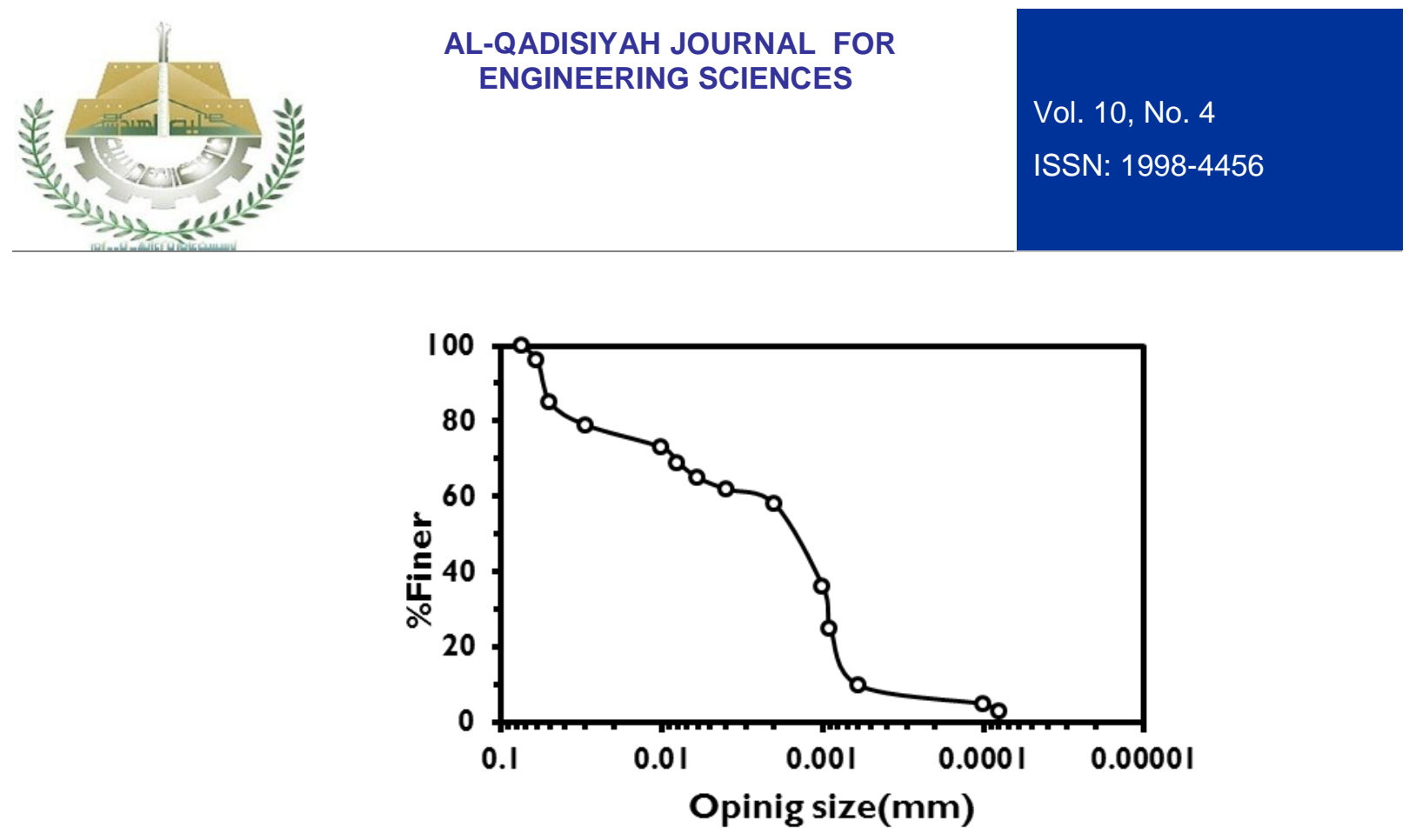

Figure 1: Grain size distribution curve for soil used

\subsection{LIME}

The lime used in this study is a hydrate lime $\left(\mathrm{Ca}(\mathrm{OH})_{2}\right.$ and it was brought from the Nora factory in Karbala, Iraq. Table2 presented the chemical composition of lime used.

Table 2: chemical composition of lime.

\begin{tabular}{|c|c|}
\hline Compound & Content, \% \\
\hline $\mathrm{CO}_{2}$ & 2.84 \\
\hline $\mathrm{CaO}$ & 69.3 \\
\hline $\mathrm{Ca}(\mathrm{OH})_{2}$ & 91.48 \\
\hline
\end{tabular}

\subsection{POZZOLANA}

As stated earlier the dates nucleus was used as an additives (pozzolanic materials). The dates nucleus was brought from the Factory of Date Molasses in Al-Hilla city as a waste product. The materials were grinded by mechanical machine and then burned at $900{ }^{\circ} \mathrm{C}$ for one hour (5). The Metakaolin powder named (DNP) was mixed with clayey soil at four percentages by dry weight namely: $5 \%, 7.5 \%, 10 \%$, and $15 \%$.

\section{METHODOLOGY}

\subsection{BASIC PROPERTIES TESTS}

After oven drying of soil at $\left(105^{\circ} \mathrm{C}-110^{\circ} \mathrm{C}\right)$ for 24 hours and mixing with the DNP at different by weight percentages, many tests were conducted, for example, wet sieving, hydrometer analysis tests in according to ASTM D421 and D422, respectively. Liquid limit and plastic limit tests are also conducted on the soil. Clay- lime mixture and DNP-Clay mixture for all percentages were executed according to ASTM D421-58. 


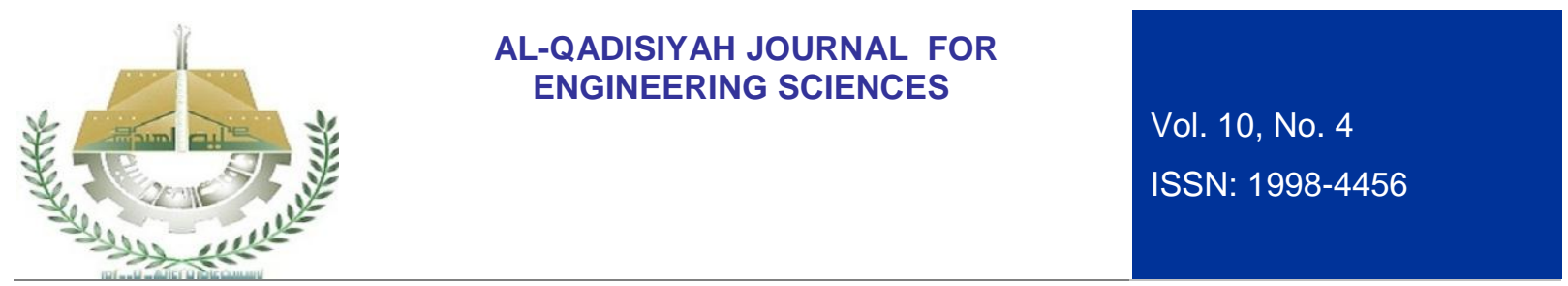

Maximum dry density and optimum moisture content were determined from the standard Proctor test for all soil samples (untreated soil, Clay-lime and DNP-Clay) according to ASTM D698-78.

\subsection{UNCONFINED COMPRESSION TEST (UCS)}

Unconfined compression tests (UCS) were used to evaluate the shear strength of the soil. All soil samples were tested in UCS according to ASTM D2166, D2166M-16. Curing time applied on all tested samples for 7, 14, 28, 56, 90, and 180 days to evaluate the stabilizer effect on long term. Only one percent of clay-lime mixture is used for a comparison between the effect of pozzolana in the lime and the pozzolana that was obtained from the dates nucleus. The 3.8\% lime by weight was selected to produce Lime-Clay mixture. This percentage was determined depending on the procedure suggested by U.S. army corps of engineering (10). A 38- $\mathrm{mm}$ in diameter by 76- $\mathrm{mm}$ height mold was used in this test. The samples extruded from the compaction mold which compacted at maximum dry density (MDD) and optimum moisture content $(\mathrm{OMC})$. All samples were coated by plastic bags and then stored in plastic containers till the time of tests.

\subsection{CALIFORNIA BEARING RATIO TEST (CBR)}

The cylindrical soil specimens had dimensions of 152-mm diameter and 127-mm height. The samples were prepared according to BS 1377: part 4: 1990 clause 7.2.4. Using the machine of compaction, the load was applied with a strain rate of $(1 \mathrm{~mm} / \mathrm{min})$. A load cell of $5-\mathrm{kN}$ having steel road $(50 \mathrm{~mm})$ diameter was fixed at the top of the frame of device to measure the load applied to the sample. Moreover, a surcharge load of 50-N was used as recommended by BS 1377: part 4: 1990: clause 7.4.2.3, and 7.4.3.4.

\section{RESULTS AND DISCUSSION}

\subsection{EFFECT OF DNP ON SOIL GRADATION AND CLASSIFICATION}

The control soil (i.e. untreated soil) was passing from sieve No.200 (i.e. 100\% passed \#200 sieve) therefore, extended gradation test represented by hydrometer analysis is performed. The results shows that the clay fraction in the soil was $58 \%$ and the activity $A=0.61$, so the soil was classified as a non-active material. Figure 2 shows the plasticity chart and the effect of stabilizers on Atterbrag's limits. It is believed that the soil is agglomerated and the grading transform from clay to silt zone as shown in Figure 2 On the other hand, Figure 3 showed that adding 10\% of DNP lead to produce soil of a lower plasticity than other DNP percentages. However, soil treated with lime experienced more roughness than other samples. The same conclusions were observed by other researchers (11). 

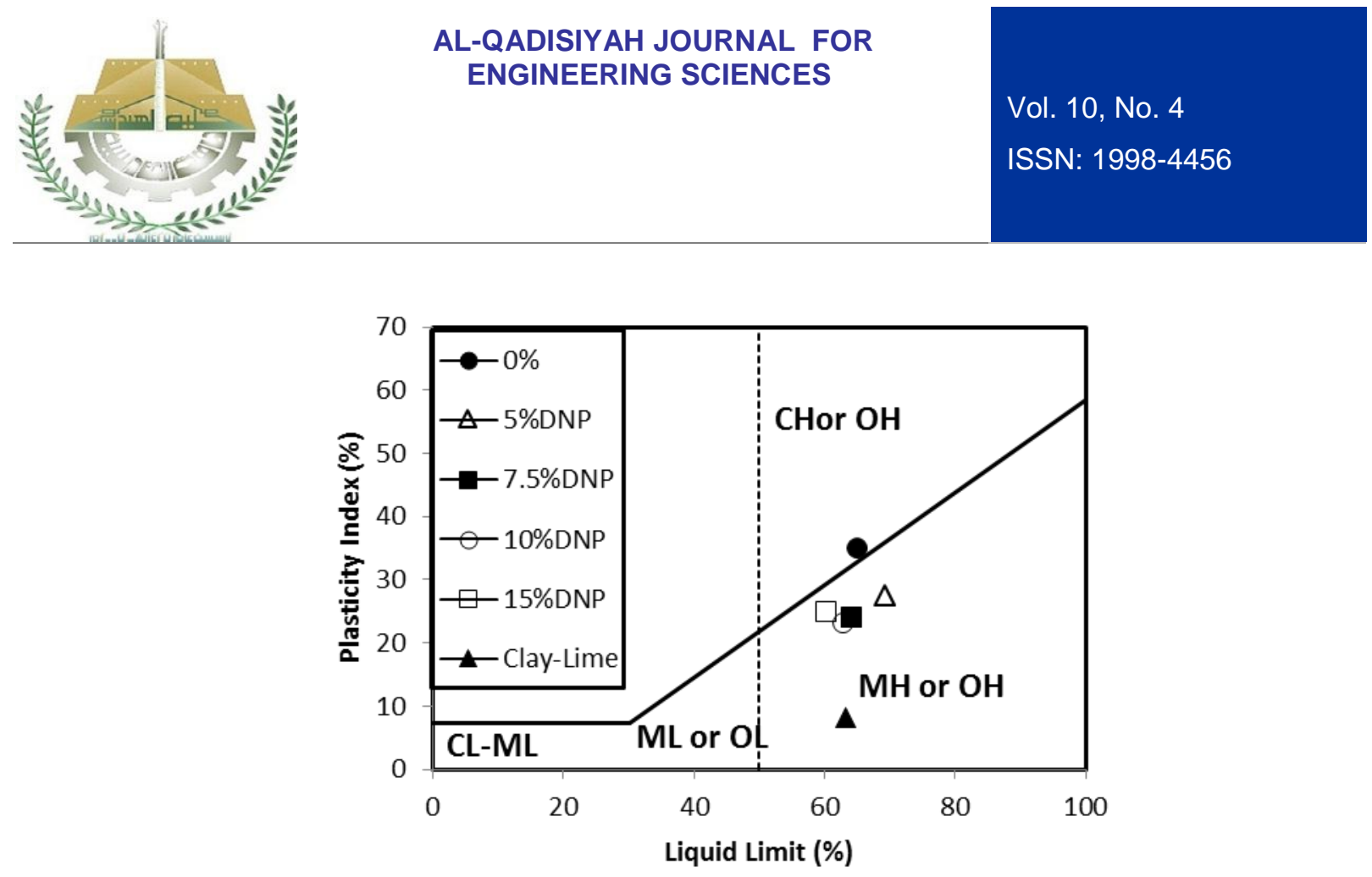

Figure 2: Plasticity chart for all samples used.

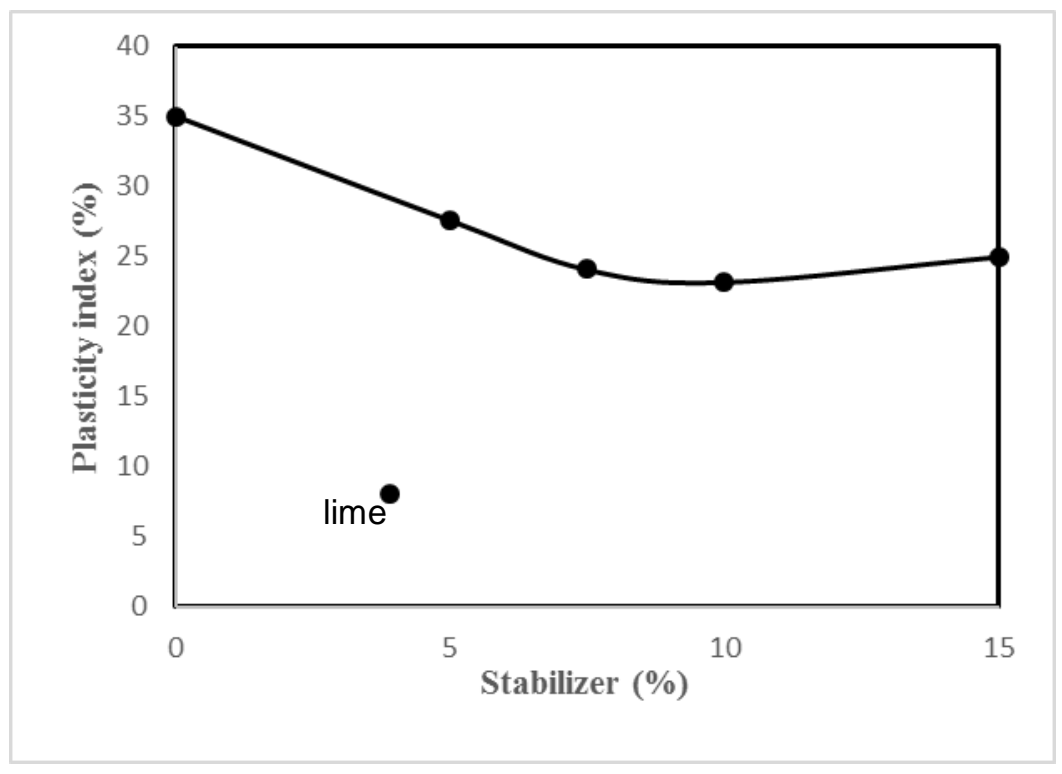

Figure 3: plasticity index results for all samples used.

\subsection{EFFECT OF DNP ON MOISTURE-DENSITY RELATION (COMPACTION)}

Figure 4 shows the results of the compaction tests, a decrease in maximum dry density with the increase in the optimum moisture content for sample treated with lime is observed. On the other hand, the samples treated with DNP shows an increase in the maximum dry density at 5\%DNP then a decrease for other percentages. The decrease in maximum dry density with the increase in optimum moisture content can be attributed to the density of stabilizer which was less than the maximum density of the soil used. On the other hand, the small particle size of stabilizer caused an increase in total surface area of the mixture at the short time stage (before chemical reaction). This trend is noticed by other researchers $(1,6,8,11)$. 

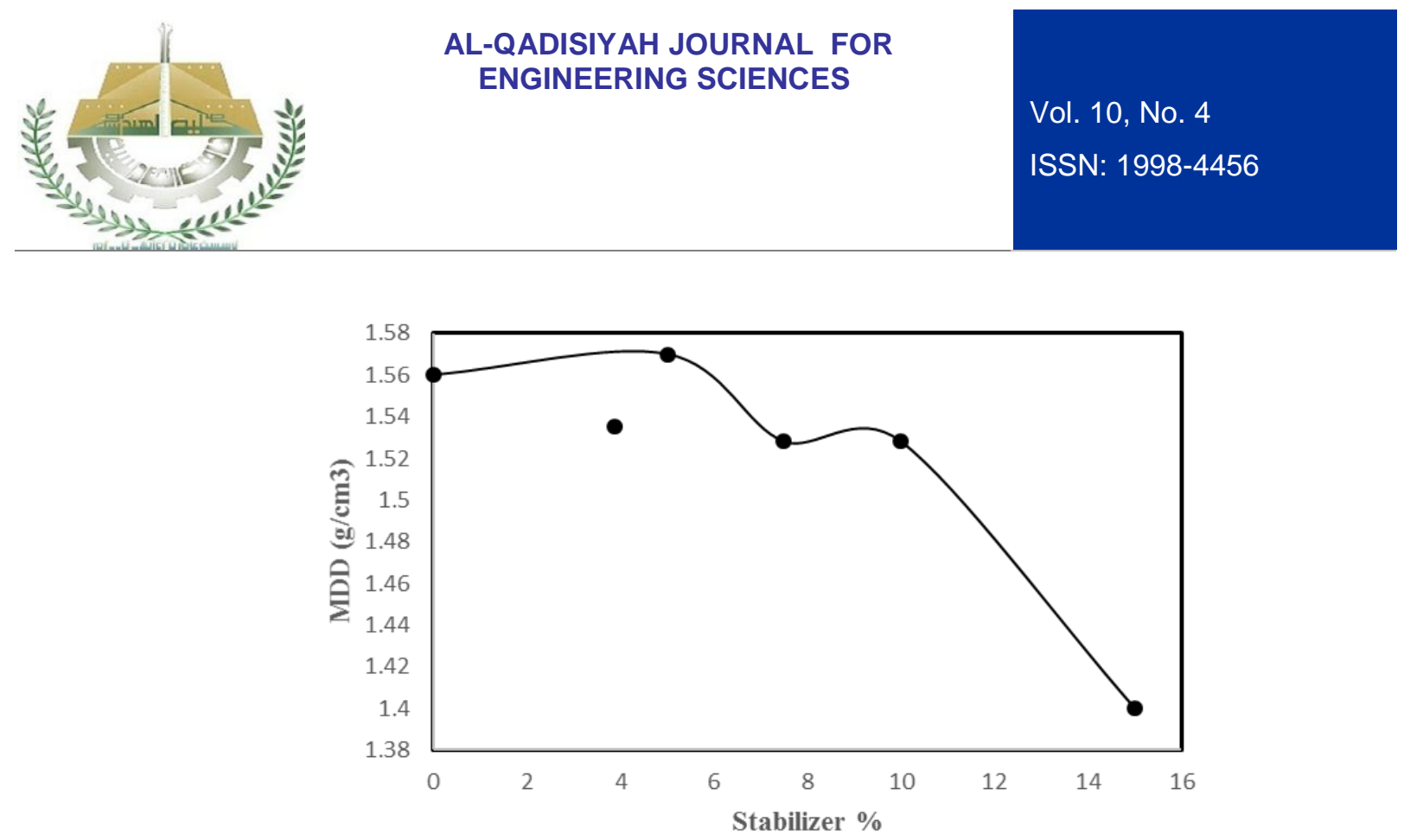

Figure 4: Maximum dry density for different samples used.

\subsection{EFFECT OF DNP ON CALIFORNIA BEARING RATIO (CBR) VALUES}

CBR tests are performed for samples at different conditions. As shown in Figure 5, increasing in CBRvalue for both conditions (soaking and un-soaking) with curing time increasing are observed. In the case of un-soaking condition, the CBR-value increased about 1067\% (from 3 for untreated soil to 35 for $10 \%$ DNP with soil). The soaking condition also shows an increase of about $1700 \%$ (from 1.5 for untreated soil to 27 for $10 \%$ DNP with soil). Furthermore, the soil treated by lime also shows increasing in CBR of about $767 \%$ for un-soaking condition (from 3 for untreated soil to 26 for 3.8\%lime with soil). The lime-clay soil mixture in soaking condition show an increase in CBR of about 1233\% (from 1.5 to 20 for untreated soil and lime-clay mixture respectively). The results also revealed that the treated specimens by DNP was better than those treated by lime due to the increasing in the strength of about $300 \%$ of soil treated by lime to soil treated by DNP as discussed before.

The results obtained from CBR tests showed that the (untreated) soil was improved from increasing its strain characteristics. The results refer to modify the untreated soil to use in base and sub-base layer in road construction as recommended by Eren and Filize 2009. Eren and Filize 2009 classified the soil according to its CBR number into five zones starting from bad if $C B R$ is between 0 and 3 in the first zone and ends in a very well in zone five if soil has CBR of more than 50. The experimental results in this study shows that the modified specimens by 10\%DNP lies in the fourth zone which has CBR of between 20 to 50 as shown in Figure 5 The change in shear strength (CBR) for treated specimens can be attributed to pozzolanic reaction that leads to agglomeration and flocculation of the clay particles and change the soil texture from highly plasticity clay to silty soil. The results also showed that the increase in CBR-values for DSP-Clay mixture are more than that for the lime- clay mixture for similar soaking conditions.

The results obtained from this experimental work is correlated with the results presented by Amu et al., 2011, and Muthyalu et al., 2012. Examining the effect of using different chemical stabilizers on CBR, Rahman, 1986 found different behavior for the same type of soil. 

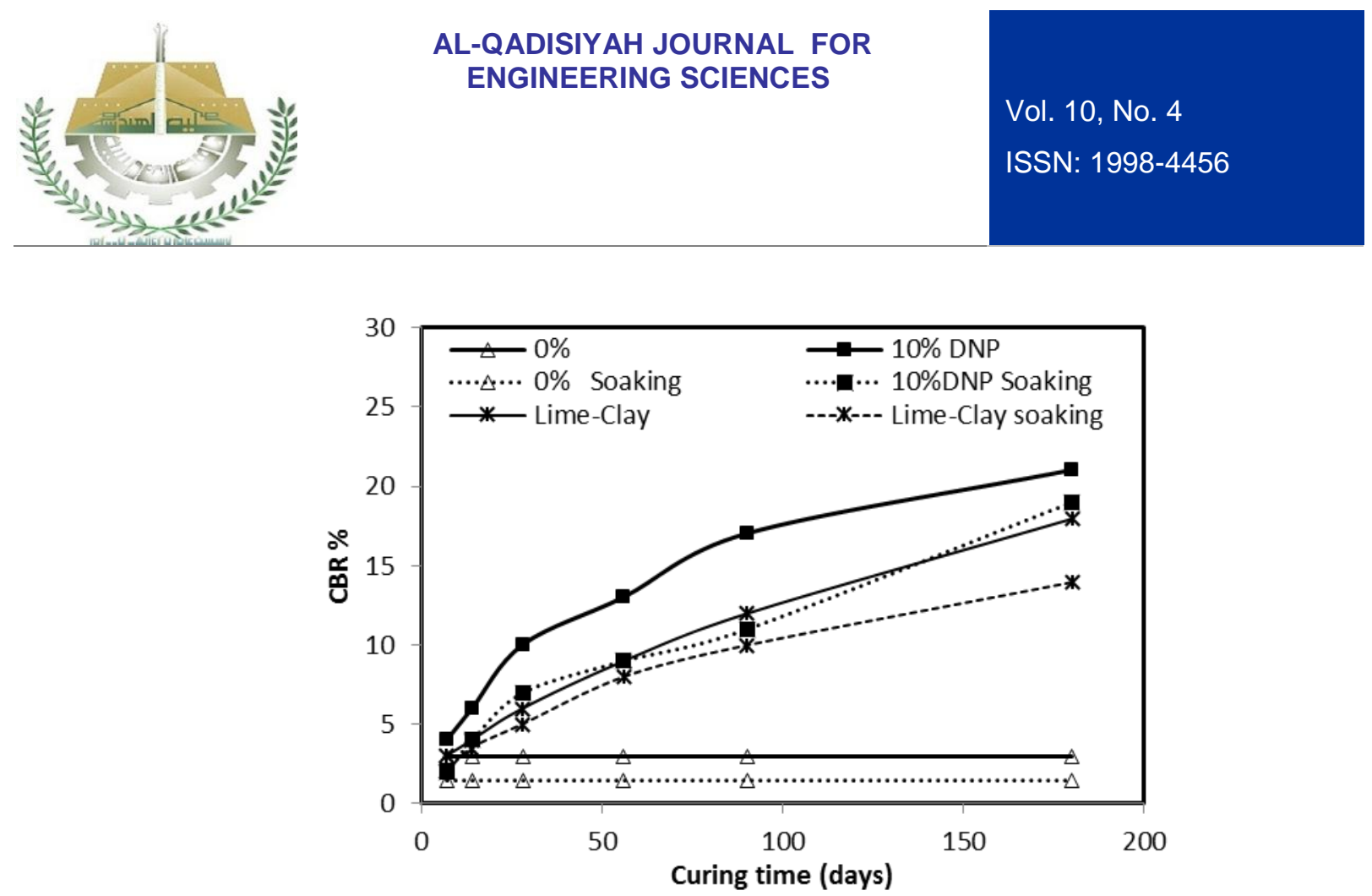

Figure 5: CBR-value results for soaking and un-soaking state of untreated soil, 10\%DNP-Clay and Lime-Clay for different curing time.

\subsection{EFFECT OF DNP ON UNCONFINED COMPRESSIVE VALUES}

Figures 6 and 7 show the effect of the percentages of DNP on the strength of soil at different curing ages. The shear strength enhanced as the DNP percentage increased till 10\% then started to decrease. The decreasing in shear strength after $10 \%$ may be attributed to the chemical reaction between alumina $\mathrm{Al}_{2} \mathrm{O}_{3} .2 \mathrm{SiO}_{2}$ in clay structure and the pozzolana in DNP. The quantity of alumina in clay particles reacted completely with pozzolana in DNP, therefore, the shear strength began to decrease. On the other hand, the shear strength of lime treated samples was less than that of samples made with other percentages of DNP. This behavior may be attributed to the generated pozzolanic reaction of lime which may less than the quantity of alumina in clay particle, therefore, the soil has low strength. The shear strength also increased to about $577 \%$ for 180 days curing period for 10\%DNP while the increasing in shear strength was about $244 \%$ for lime-clay mixture. Also the results showed about $97.5 \%$ increasing for 10\%DNP more than the same soil treated by lime-clay mixture after 180 days of curing.

Figure 7 shows the stabilizer agent percentages on shear strength of soil. The samples used in this figure are cured for 180 days. The results showed an increase in shear strength with increasing DNP percent till $10 \%$ then began to decrease after that. The increase in shear strength of $10 \%$ DNP was about $577 \%$ after 180 days curing period while the corresponding increase for lime-clay mixture was $243 \%$. The results showed that the treated soil by DNP was better than the soil treated by lime for the same soil conditions. 


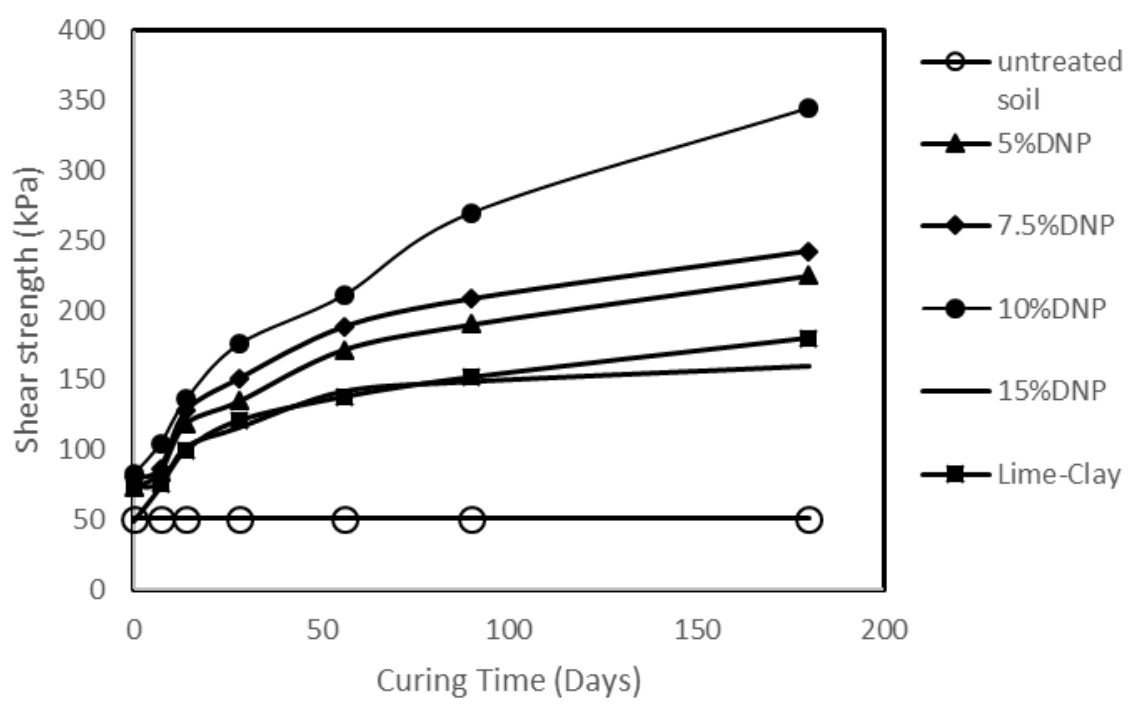

Figure 6: Effect of curing time on shear strength of soil treated by DNP and lime.

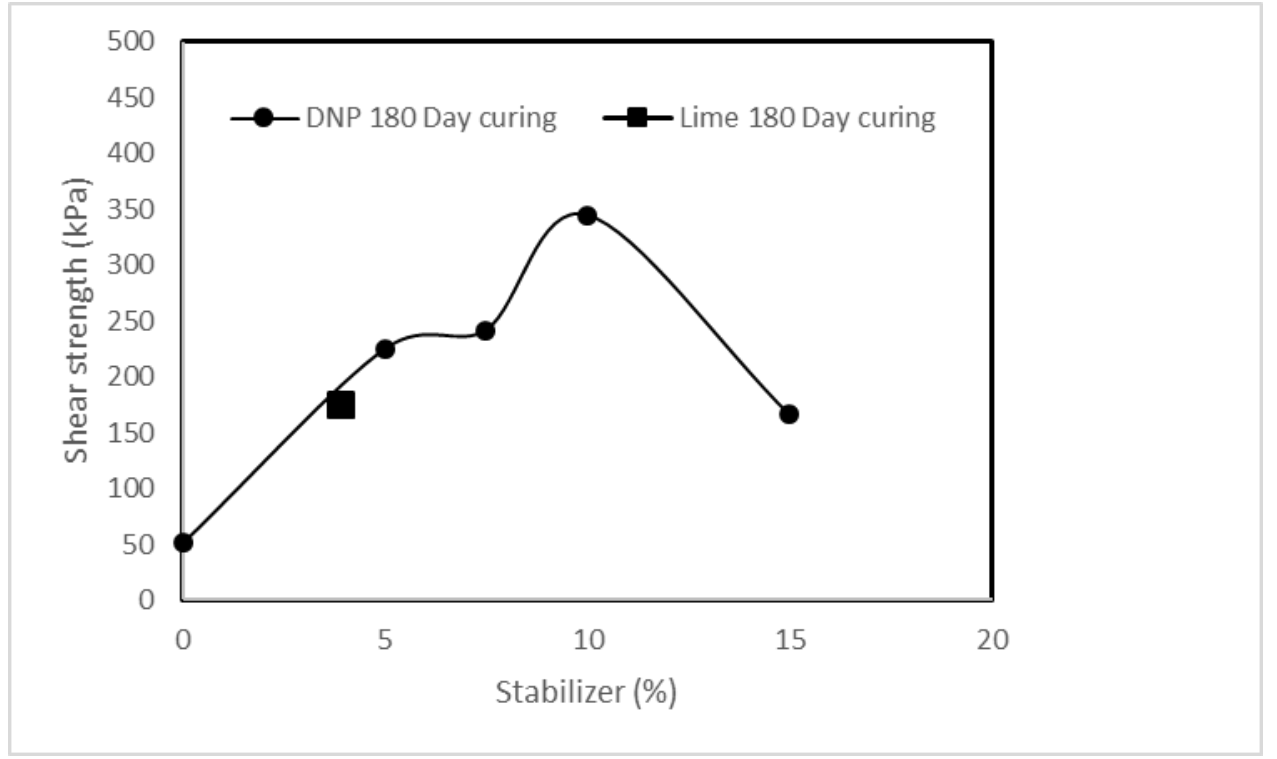

Figure 7: Effect of stabilizer on soil strength.

\section{CONCLUSIONS}

From the results discussed earlier, the following conclusions may be drawn:

1- The addition of $10 \%$ DNP to the clayey soil has a significant effect in improving its shear strength.

2- Among the four percentages of DNP added to clay, the highest shear strength was achieved at $10 \%$.

3- The percentage of DNP added to the clayey soils depended on the percent of clay particles such that the DNP effects increase as the clay particles increase. 


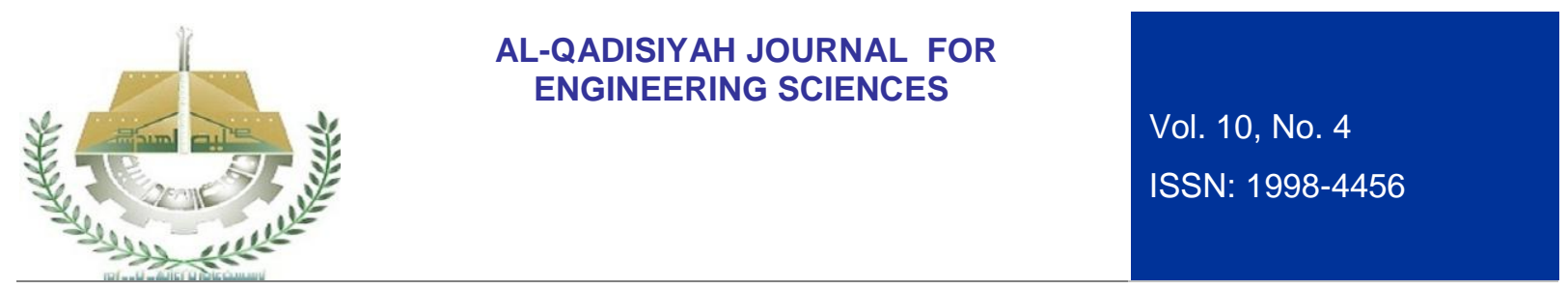

4- Using DNP is healthier than use of lime because the DNP is organic materials with no chemical effects on the environments and human.

5- The promising results obtained from this study encourage the use of the DNP as a stabilize agent to improve soil strength characteristics in general.

\section{REFERENCES}

1. Basha E.A., Hashim R., Mahmud H.B., and Muntohar A.S., Stabilization of residual soil with rice husk ash and cement" Construction and Building Materials, (2005) Vol.19 Pp448-453.

2. Ahmed F., Atemimi Y.K, Ismail A.M, "Evaluation the Effects of Styrene Butadiene Rubber Addition as a New Soil Stabilizer on Geotechnical Properties "EGEJ (2013) Vol.18 Bund D Pp 735-748.

3. Kassim K.A, " The effect of catalyst on soil stabilization by application of lime" University Technology Malaysia, Research vote no.: 78104. (2009).

4. Saeed K.A and Atemimi Y.K, The Strength Behavior of Lime Stabilized Organic Clay Soil Modified by Catalyst Additives" Journal of Babylon University/Engineering Sciences, (2016) No.(4)/ Vol.(24).

5. Sabir B.B., Wild S. and Bai J, Metakaoline and calcined clays as pozzolans for concrete, a review" cement and concrete composites" (2001) Vol.23,Pp441-454.

6. Bagheri Y., Atemimi Y.K., Ahmad F., Ismail M.A.," Soil Strength improvement by using a new compound stabilizer" Caspian Journal of Applied Sciences Research, (2012) Vol.2 (AlCCE'12 \& GIZ' 12), Pp. 84-90.

7. Alamdari A.S., Dabiri R., "Effect of the fibers type on improving the bearing capacity of clayey soils" International Journal on Technical and Physical Problems of Engineering (IJTPE) (2017), Issue 30 Volume 9 Number 1 Pp 43-50.

8. Kim Y. , and Do T." Effect of bottom ash particle size on strength development in composite geomaterial" Engineering Geology, (2012) Vol.139-140 Pp. 85-91.

9. ASTM, “Annual Book of ASTM standards. ASTM International, West Conshohocken, PA, www.astm.org., 2005;04-08.

10. Krishna R.M, Vincent P., Kim D., "Family of compaction curves for mechanically modified soils" FHWA/IN/JTRP-2005/7.

11. Atemimi Y.K.,and Saeed K.A, "Study the Effect of Date Seed Powder on the Strength of Kaolinite Clay Soil" Muthanna Journal of Engineering and Technology (MJET), ,(2016)" Pp88-94.

12. Eren,S., and Filiz M., "Comparing the Conventional Soil Stabilization Methods to the Consolid System Used as an Alternative Admixture Matter in Isparta Darıdere Material. Construction and Building Materials, .,(2009). Vol. 23, 2473-2480.

13. Amu, O.O., and Babajide, S.S., "Effects of Bamboo Leaf Ash on Lime Stabilized Lateritic Soil for Highway Construction. Research Journal of Applied Sciences, Engineering and Technology, 2011 Vol. 3, Pp 278-283.

14. Muthyalu, V.P., Ramu, K. and Prasada Raju,. G.V.R.,"Study on Performance of Chemically Stabilized Expansive Soil". International Journal of Advances in Engineering and Technology, 2012). Vol.2, Pp 139148.

15. Rahman,M. A., "The Potential of Some Stabilizers for the Use of Lateritic Soil in Construction". Building and environmental, 1986 Vol. 21,Pp 57-61. 